\title{
CHEMICAL TREATMENT TO UNCLOGG DRIPPER IRRIGATION SYSTEMS DUE TO BIOLOGICAL PROBLEMS
}

\author{
Túlio Assunção Pires Ribeiro ${ }^{1 *}$; José Euclides Stipp Paterniani²; Christiane Coletti² \\ IUNICAMP/FEAGRI - Depto. de Água e Solo na Área de Qualidade da Água para Irrigação, C.P. 6011 - \\ 13083-970 - Campinas, SP - Brasil. \\ ${ }^{2}$ UNICAMP/FEAGRI - Depto. de Água e Solo. \\ *Correspondigauthor <tulior@agr.unicamp.br>
}

\begin{abstract}
Many producers use drippers for trickle irrigation systems for flower production in the field and in protected environments. A frequent problem in this type of irrigation system is the clogging of drippers, which is directly related to water quality and filtering system efficiency. The objective of this study was to conduct an experimental investigation to evaluate the efficiency of using nitric acid and sodium hypochlorite to unclogg drippers due to the use of water with high algae content. The evaluation was conducted in six, $4216 \mathrm{~m}^{2}$ greenhouses, each with two sectors comprised of ten spaces or lines, totaling 12 sectors of a dripper irrigation system in a rose producing property of Holambra, State of SP, Brazil. Chemical and physical analyses and the bacteriological count in water were carried out in the three water sources that supply the irrigation system to check the factors causing the clogging. Evaluations were carried out on water distribution uniformity in all sectors before and after chemical treatment in order to evaluate efficiency. The treatment improved water distribution uniformity and a lead to a reduction in the coefficient of variation (CV) for dripper flow in all sectors. There was a good correlation between $\mathrm{CV}$ and the water distribution uniformity index. Therefore, this is an excellent method to be used to unclogg drippers due to biological problems.

Key words: trickle irrigation, uniformity evaluation, chlorinate, water quality
\end{abstract}

\section{DESENTUPIMENTO DE UM SISTEMA DE IRRIGAÇÃO POR GOTEJAMENTO DEVIDO A PROBLEMA DE ORIGEM BIOLÓGICA}

\begin{abstract}
RESUMO: Muitos produtores usam gotejadores para irrigação localizada em produção de flores no campo e em ambientes protegidos. Um problema freqüente neste tipo de irrigação é o entupimento dos gotejadores, que está diretamente relacionado à qualidade da água e à deficiência de filtração do sistema. Este trabalho teve como objetivo fazer uma investigação experimental para avaliar a eficiência da utilização de ácido nítrico e de hipoclorito de sódio na desobstrução de gotejadores entupidos, devido à utilização de águas com elevado teor de matéria de origem biológica. A avaliação foi realizada em seis estufas de $4216 \mathrm{~m}^{2}$, sendo que cada estufa tem dois setores, composto de dez vãos ou linhas em cada setor, totalizando 12 setores de um sistema de irrigação por gotejamento, em propriedade produtora de rosas (Rosa sp.), sob estufa plástica, no município de Holambra, SP. Análises química, física e de contagem bacteriológica da água foram realizadas nas três fontes hídricas que abasteciam o sistema de irrigação, para verificar quais os fatores que estavam causando risco de entupimento. Foram feitas avaliações da uniformidade de distribuição de água em todos os setores antes e depois do tratamento químico com o intuito de avaliar a sua eficiência. Ocorreu melhora na uniformidade de distribuição de água e diminuição no coeficiente de variação de vazão $(\mathrm{CV})$ dos gotejadores em todos os setores. Houve boa correlação entre o CV e o índice de uniformidade adotado nesta pesquisa. Portanto este é um excelente método para ser utilizado na desobstrução de gotejadores entupimentos devido a problemas de origem biológica. Palavras-chave: irrigação localizada, avaliação da uniformidade, cloração, qualidade de água
\end{abstract}

\section{INTRODUCTION}

In Holambra, State of São Paulo, Brazil a high number of producers use drippers for trickle irrigation systems for flower production in the field and in protected environments. A frequent problem in this type of irrigation system is the clogging of drippers, which is directly related to water quality and filtering system efficiency.

The water supply in the region consists predominantly of superficial water sources with high incidence of temperatures in the optimal range for mi- 
croorganism growth (mostly algae and bacteria), resulting in a high risk of biological clogging of trickle irrigation systems. There are products for treating clogged or partially clogged drippers that remove the attached slime from tubing walls and drippers. Acids can be used to lower the water $\mathrm{pH}$ and reduce the potential for chemical precipitation (Pitts et al., 2003). Sulfuric $\left(\mathrm{H}_{2} \mathrm{SO}_{4}\right)$, hydrochloric $(\mathrm{HCl})$, phosphoric $\left(\mathrm{H}_{3} \mathrm{PO}_{4}\right)$ and nitric $\left(\mathrm{HNO}_{3}\right)$ acid are used for this purpose. Direct action against bacteria is achieved by applying biocides, chlorine being the mostly used in its gaseous form or as sodium hypochlorite in its liquid form, injected before the filtering system. Chlorination is effective for partial but not total unclogging of drippers (Resende, 1999). Excellent results were obtained in the prevention of clogging of four types of dripper tapes of different brands, utilizing wastewater treated with a combination of filtration (a sand filter and a screen filter with pores of $100 \mu \mathrm{m}$ in diameter) with intermediate chlorination (free residual chlorine in the concentration of $0.4 \mathrm{mg} \mathrm{L}^{-1}$ ), according to assays carried out by Hills \& Brenes (2001). Although the chlorination can be efficient for the prevention of clogging, there is no consensus between researchers in relation to amount, frequency and best way of application (Airoldi, 2007).

Therefore, this study had the following objectives: Evaluate the water distribution uniformity index of 12 sectors of greenhouses with serious clogging problems; Verify the efficiency of a chemical treatment, using nitric acid and sodium hypochlorite to recover clogged or partially clogged drippers; Analyze water quality and verify which factors were causing clogging of the irrigation system.

\section{MATERIAL AND METHODS}

Six $4216 \mathrm{~m}^{2}$ plastic greenhouses were used, each with two sectors comprised of ten spaces or lines per sector, totaling 12 sectors of a dripper irrigation system on a rose (Rosa sp.) producing property, in Holambra, State of São Paulo, Brazil, (22 $37^{\prime}$ ' S and $47^{\circ} 03^{\prime} \mathrm{W}$ ). Each evaluated sector had an irrigated area of $2108 \mathrm{~m}^{2}$, comprised of 33 lines, each 33 meters long with $12 \mathrm{~mm}$ inner diameter tubing, using an AquaTraxx dripper belt, model 6 mil and nominal flow of $1.41 \mathrm{~L} \mathrm{~h}^{-1}$ at the pressure of $68.64 \mathrm{kPa}$; the drippers were spaced at $0.3 \mathrm{~m}$ on the line and $1.8 \mathrm{~m}$ between lines and the filtering system consisted of a sand filter and a $(130 \mu \mathrm{m})$ disc filter. The evaluated drippers had been in operation for approximately 15 hours, or an average of two months of use. The variation in the degree of dripper clogging was made through the variation in the quality of the reservoir irrigation wa- ter, which was mainly supplied by superficial waters, but also by well water. At the entrance to each sector, there is a pressure regulator to obtain a pressure of $103.42 \mathrm{kPa}$. Five dripper lines were evaluated in each sector; three lines were located at the beginning, in the middle and at the end of the sector. The drippers were located at the beginning, 1/3, 2/3 and end of the line. The other two lines were located in the middle between the last line and the middle one and between the middle line and the first one of the sector, and the drippers were at the beginning, middle and end of the line, totaling 18 points per sector (Figure $1)$.

Dripper flow was measured using the volumetric method for a three-minute collection period and the pressure was measured at the end of the side lines using a new, previously calibrated, Bourdon gauge with a precision of $10 \mathrm{kPa}$.

Based on the flow and average pressure of collected data, the technical data for the characteristic pressure curve were compared to the dripper flow according to assays conducted by Cararo (2004) in a laboratory, using the equation:

$\mathrm{Q}=0.1269 * \mathrm{H}^{0.589}$ in which $\mathrm{Q}\left(\mathrm{L} \mathrm{h}^{-1}\right)$ and $\mathrm{H}(\mathrm{kPa})$

The test revealed serious dripper clogging problems in most of the sectors as it can be observed in Figure 2.

The water was chemically treated using sodium hypochlorite $(\mathrm{NaClO})$, which has $12 \%$ free chlorine, at a concentration of $100 \mathrm{mg} \mathrm{L}^{-1}$, together with nitric acid $\left(\mathrm{HNO}_{3}\right)$ at concentration $65 \%$, used to lower the solution $\mathrm{pH}$ since when sodium hypochlorite is added to water there is a not desired increase in $\mathrm{pH}$. To determine the amount of acid to be added to the irrigation water, a titration was made. During the applications, water samples were collected from the drippers to confirm the solution $\mathrm{pH}$. The water $\mathrm{pH}$ was kept around five in order to permit a greater concentration of hypochlorous acid in the solution.

During the applications, water samples were collected from the more distant drippers, and the solution $\mathrm{pH}$ and free chlorine content were then measured, using a $\mathrm{pH}$ meter and a $\mathrm{HACH}$ kit which uses D.P.D. ( $\mathrm{N}$ - diethyl - $\mathrm{p}$ - phenyl - diamin) to measure the free chlorine. The rate was $0.5 \mathrm{mg} \mathrm{L}^{-1}$ of free residual chlorine in the most distant dripper. This concentration was based on the principle that all chlorine reacts with compounds present in the water, including the action on bacteria that form biofilms. This small amount only represents a residual safety margin for the reactions. Other reasons for choosing this concentration were the low possibility of phytotoxicity and the lower cost in acquiring the chlorinated product. 
The concentration used was also based on recommendations by Keller \& Bliesner (1990) and Tajrishy et al. (1994), who also suggest relatively low concentrations, such as $2 \mathrm{mg} \mathrm{L}^{-1}$ intermittently and $1 \mathrm{mg} \mathrm{L}^{-1}$ or $0.4 \mathrm{mg} \mathrm{L}^{-1}$ continuously.

The chemical products were injected into the main tubing using an injection control system comprised of a piston pump driven by an electric motor, with two injection chambers thus making it possible to inject two products at the same time. The separate application feature for chemical products is necessary because in the case of chlorine applications, these must be applied separately from the acid to avoid any possible chemical reactions. Before application, all sectors were evaluated in order to permit a comparison of the results with the initial uniformity values. Two applications were made. After the first evaluation, the first application was made, lasting 25 minutes, whereas the second lasted one hour and fifteen minutes. During the applications, the first 15 minutes were considered to correspond to the time required for the chemical solution (nitric acid plus sodium hypochlorite) to moved to the end of the irrigation lines. The time after was meant for the reactions with the organic compounds, iron and phosphorus. It is believed that this time was sufficient for these reactions to occur, because most of the viruses and bacteria are deactivated after 10 to 30 minutes of contact.

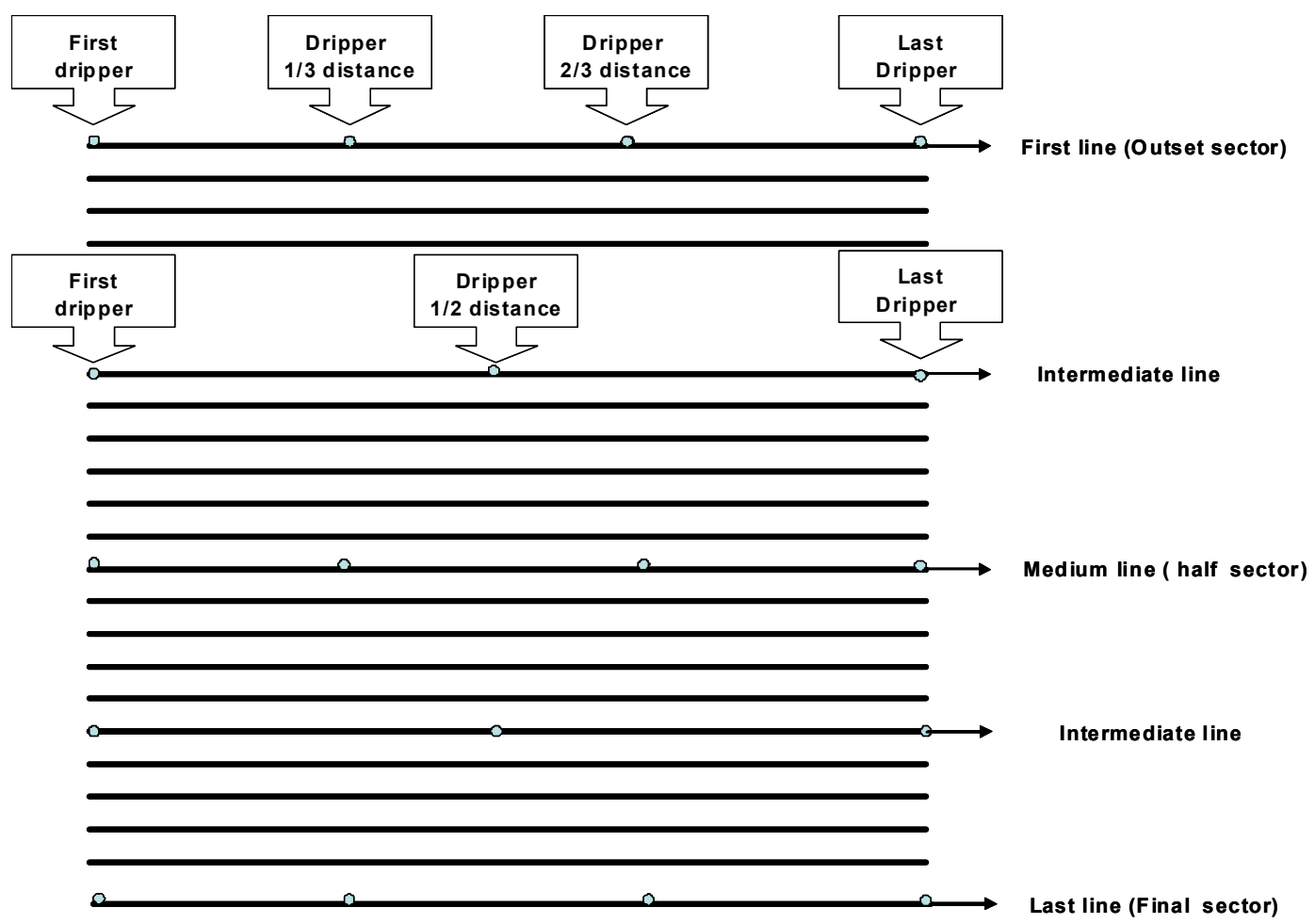

Figure 1 - Uniformity test plan for choosing drippers in each sector.

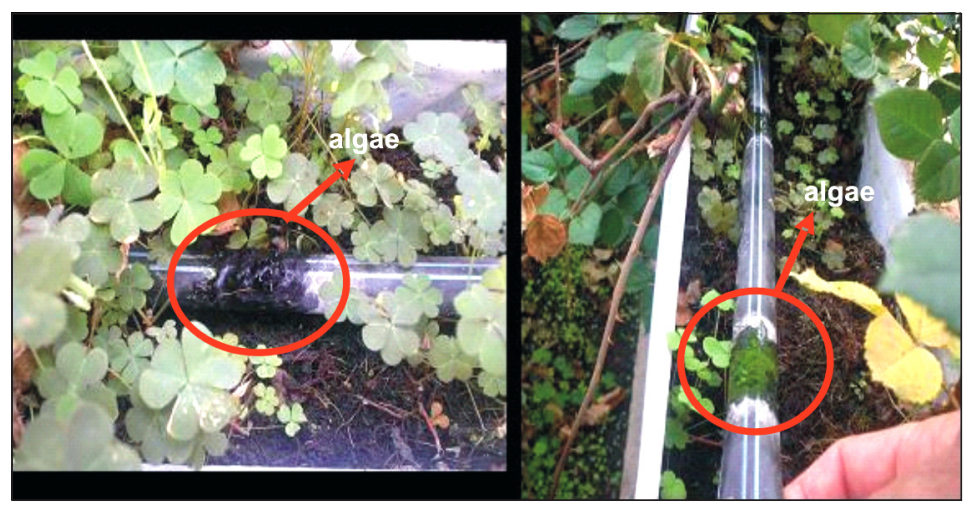

Figure 2 - Detail showing the formation of algae in the external part of the lateral lines of the evaluated sectors. 
In a research performed at the Sewage Treatment Station in Lins, State of São Paulo, Brazil, similar contact times were used for chlorine (15 minutes) with disinfection purposes (Rodrigo López et al., 1997). Besides that, the presence of accessories in the tubing lines such as curves, tees, registers and reducers imposes a turbulent regime in the water that helps to mix the sodium hypochlorite in the water and consequently helps in the reactions with the substances present in the water, and at the end with the free residual chlorine remaining in the form of $\mathrm{OCl}^{-}$ and/or $\mathrm{HOCl}^{-}$, depending on the $\mathrm{pH}$. The ten minute application was necessary to avoid loosening larger particles and having them end up in the dripper, thus making the clogging worse. At the end of the application, the system was immediately shut off and left to rest for approximately 12 hours, when the ends of the line were opened and the system turned on again to wash the tubing, which were closed as soon as the output of clean water for at least three minutes was ascertained, thus guaranteeing that all loose material had been eliminated from the system. After the cleaning process was concluded, another evaluation was made. After concluding the evaluation, some drippers were opened to check the degree of clogging. But it was not possible to open them since the drippers were molded to the piping. The internal walls of the hoses were also observed to check for any accumulation of iron precipitates that could be present in the irrigation water.

Preliminary analyses of the factors related to irrigation water quality and that could cause obstructions in the drippers were made for the trickle irrigation system. These included: $\mathrm{pH}$, solids in suspension, turbidity, dissolved solids, electric conductivity, iron, manganese, total hardness, alkalinity, Langelier index and bacteria concentration. The classification of the water for the trickle irrigation system in relation to clogging problems followed the recommendations of Nakayama \& Bucks (1991) and Ribeiro et al. (2004). The water used for irrigation comes from a $250 \mathrm{~m}^{3}$ reservoir, comprised of a small dam that is supplied by two sources; the first by pumping water from a dam that receives water contribution from other springs in the surrounding area, and the second from an artesian well, the greatest contribution was comming from the dam.

In order to determine water distribution uniformity, the method proposed by Bralts \& Kesner (1983) was used, but a computer program developed by Zazueta \& Smajstrla (2002) was used for the calculations which consists of using a statistical method to estimate water distribution uniformity in the field or sectors based on the coefficient for statistical unifor- mity (Us) (equation 1) and the coefficient of variation (CV) (equation 2):

$\mathrm{Us}=100(1-\mathrm{CV})$

where: Us = statistical uniformity of emission (\%); CV $=$ statistical coefficient of variation for the emitter flow.

$C V=\mathrm{s} / \mathrm{q}$

where: $\mathrm{s}=$ standard deviation $(1 / \mathrm{h}) ; \overline{\mathrm{q}}=$ total average flow $(1 / \mathrm{h})$.

The greater the variation of the emitter flow values, the lower the uniformity of the application (Equation 1). In equation 2, the value of the CV includes the variation in emitter flow due to all causes, including piping effects and emitter hydraulic characteristics, which includes the obstruction.

\section{RESULTS AND DISCUSSION}

\section{Water quality related to clogging risk}

Among the factors shown in Table 1 and other found in literature as restrictive to the use of water for trickle irrigations systems (Nakayama \& Bucks, 1991 and Ribeiro et al., 2004), it was verified that there was no restriction for the well water. For the reservoir, iron presented a moderate risk and phosphorus a high risk, whereas in the supply lake there was a moderate restriction to $\mathrm{pH}$ and iron and a high restriction for phosphorus. The alkalinity values probably correspond in the most part to the presence of bicarbonate $\left(\mathrm{HCO}_{3}^{-}\right)$, which revealed a low risk for clogging. The same occurred with regard to hardness (Pitts et al., 2003), with values considered of low clogging potential in relation to the formation of $\mathrm{CaCO}_{3}$ precipitates. Bicarbonate concentrations of more than $5 \mathrm{meq}$ $\mathrm{L}^{-1}$, or $305 \mathrm{mg} \mathrm{L}^{-1}$, caused serious problems due to precipitates in the irrigation system (Ayers \& Westcot, 1985). This did not occur because the water sources had low values in bicarbonate concentration. This fact is confirmed when the Langelier saturation index is observed, which is determined based on $\mathrm{Ca}^{+2}, \mathrm{Mg}^{+2}, \mathrm{HCO}^{-3}$ and $\mathrm{CO}^{+2}$ contents used to calculate water $\mathrm{pH}$, if in equilibrium with $\mathrm{CaCO}_{3}$, at a determined concentration of calcium and bicarbonate ions $(\mathrm{pHc})$ and the measured $\mathrm{pH}$, which was used in the sense of providing a systematic approximation to determine the risk of calcium carbonate precipitate formation, since there are three different sources of water that supply the irrigation system. The calculated indexes for the different water sources resulted in negative values, indicating that there was no tendency for calcium carbonate precipitation and consequent potential for clogging. 
Table 1 - Physical, chemical and bacteriological analyses from well, reservoir and lake water.

\begin{tabular}{|c|c|c|c|c|c|c|}
\hline \multirow{2}{*}{ Parameters } & \multicolumn{6}{|c|}{ Location } \\
\hline & Well & Clog Risk & Reservoir & Clog Risk & Lake & Clog Risk \\
\hline Suspended Solids $\left(\mathrm{mg} \mathrm{L}^{-1}\right)$ & 0 & None & 0.02 & None & 0.02 & None \\
\hline Turbidity (NTU) & 5.49 & Low & 13.20 & Low & 13.40 & Low \\
\hline $\mathrm{pH}$ & 4.25 & Very Low & 6.70 & Low & 7.25 & Moderate \\
\hline $\begin{array}{l}\text { Dissolved Salts } \\
\left(\mathrm{mg} \mathrm{L}^{-1}\right)\end{array}$ & 281.00 & Very Low & 109.80 & Very Low & 87.20 & Very Low \\
\hline $\begin{array}{l}\text { Electric Conductivity } \\
\left(\mu \mathrm{S} \mathrm{cm}^{-1}\right)\end{array}$ & 197.50 & Very Low & 77.40 & Very Low & 61.50 & Very Low \\
\hline Manganese $\left(\mathrm{mg} \mathrm{L}^{-1}\right)$ & $\mathrm{BLD}^{(1)}$ & None & $\mathrm{BLD}^{(1)}$ & None & $\mathrm{BLD}^{(1)}$ & None \\
\hline Iron $\left(\mathrm{mg} \mathrm{L}^{-1}\right)$ & $\mathrm{BLD}^{(1)}$ & None & 0.30 & Moderate & 0.40 & Moderate \\
\hline Phosphorus (mg L-1) & $\mathrm{BLD}^{(1)}$ & None & 1.00 & High & 1.00 & High \\
\hline Hardness (mg L-1) & 29.80 & Low & 48.20 & Low & 20.60 & Low \\
\hline Alkalinity $\left(\mathrm{mg} \mathrm{CaCO}{ }_{3} \mathrm{~L}^{-1}\right)$ & 0 & None & 17.45 & Low & 19.28 & Low \\
\hline Langelier Index & -1.35 & Extremely Low & -2.70 & Extremely Low & -2.25 & Extremely Low \\
\hline Bacterial Count $\left(\mathrm{cfu} \mathrm{cm}^{-3}\right)$ & 0 & None & 39.00 & Extremely Low & 97.00 & Extremely Low \\
\hline
\end{tabular}

The values for suspended solids and turbidity were low for all water sources and result from the fact that the reservoir is used as a supply source of still water, in which certainly sedimentation of materials in suspension take place. The concentration of iron, of 0.3 and $0.4 \mathrm{mg} \mathrm{L}^{-1}$ found respectively in the reservoir and lake waters is a little higher than the values considered as risk for precipitate formation. Problems with bacteria-iron interactions have occurred with iron concentrations as low as $0.1 \mathrm{mg} \mathrm{L}^{-1}$. Contents of this ion greater than $0.2 \mathrm{mg} \mathrm{L}^{-1}$ are considered a significant risk for clogging (English, 1985). Precipitated iron forms a red crust that can stick to the PVC tubing and clog the drippers. Some filamentous bacteria, such as Gallionella, Crenothrix and Leptothrix, oxidize $\mathrm{Fe}^{+2}$ into $\mathrm{Fe}^{+3}$ which can precipitate and cause clogging (Ford \& Tucker, 1986; Pizarro, 1996). These bacteria have an economic and sanitary importance causing the formation of iron crusts inside the tubing or residences as well as precipitate ferrous hydroxide in waters rich in this element and in tubing systems they are frequent causes of obstructions and give the water a brownish-red color. Some types of disinfectants such as chlorine and copper sulfate have been used to control these bacteria. The latter has been used successfully at rates of 0.3 to $0.5 \mathrm{mg} \mathrm{L}^{-1}$ to control ferrobacteria, such as Crenothrix (Branco, 1986). Cuts were made in the hoses used in the system to check for problems caused by iron; however no visible deposits of precipitates were observed.

The values found for the bacteriological count at the reservoir, well and lake revealed values also considered of very low risk for biological clogging. Cuts were made at the ends of the dripper lines and a large formation of biological biofilm was observed as well as the occurrence of the same formation in the dripper orifice (Figure 1). This problem was observed by Resende et al. (2001). When evaluating water distribution uniformity in a section of trickle irrigation, they found notable differences in bacterial count between sampling points, with values of 5.5 $10^{2} \mathrm{cfu} \mathrm{cm}^{-3}$ in the water source, $1.010^{3} \mathrm{cfu} \mathrm{cm}^{-3}$ after the filter system and $2.510^{7} \mathrm{cfu} \mathrm{cm}^{-3}$ at the end of a dripper line in operation. During the field evaluation, it was ascertained that several drippers located at the end of the side lines were totally obstructed, that is, without flow.

When working with biological clogs, Ravina et al. (1992) found that the final segments on the sides of the drippers tend to present a greater degree of clogging in relation to the initial segments. However, in an assay conducted by Boman (1995) for physical clogging, the same occurred in a uniformly distributed manner all along the side line.

The parameter that revealed the greatest problem in relation to clogging was phosphorus. Although there is no information about phosphorus restriction in the irrigation water for the localized irrigation system, according to Branco (1986), when this element is present in springs at concentrations of more than $0.01 \mathrm{mg} \mathrm{L}^{-1}$, it determines a mass proliferation of algae, which in turn cause serious problems for water use, whether for supply, for recreational purposes and others. High levels of nitrogen and phosphorus result in excess algae growth, which causes problems of 
eutrophization in the water. The eutrophization process of the superficial waters caused by an elevated concentration of phosphorus, promotes the mass proliferation of algae, which in turn will entail in serious clogging problems in filters and in the water distribution system (Mota, 1997). Therefore, it is important to observe the quality requirements and standards as a result of foreseen use, and which can be found in Pescod (1992) and Léon \& Cavallini (1999). The maximum limit set for total phosphate by CONAMA, 2005 in water of classes one, two and three, is 0.025 $\mathrm{mg} \mathrm{L}^{-1}$ of P. According to Sperling (1996), the following total $\mathrm{P}$ values are used: (a) $\mathrm{P}<0.01-0.02 \mathrm{mg} \mathrm{L}^{-1}$ : non-eutrophic; (b) P between $0.01-0.02$ and $0.05 \mathrm{mg}$ $\mathrm{L}^{-1}$ : intermediate stage and (c) $\mathrm{P}>0.05 \mathrm{mg} \mathrm{L}^{-1}$ : eutrophic.

The water source that contributes to algae proliferation is from the lake because it has a phosphorus concentration of one $\mathrm{mg} \mathrm{L}^{-1}$, or practically 100 times greater than acceptable. This fact can be explained because the lake water receives in natura waste from swine raisers of the area as well as agricultural pollution from properties due to excessive use of fertilizers together with erosion processes.

Evaluation of water distribution uniformity, flow and pressure of the greenhouses before and after chemical treatment

The summary of the evaluation of the $12 \mathrm{sec}-$ tors with their respective water distribution uniformity indexes, classification, flow and average pressure at the end of the sector lines before and after chemical treatment (Table 2). Shows that there was an improvement in most sectors after chemical treatment in relation to the water distribution uniformity index, and an increase in flow and average pressure at the end of the line for all sectors. Only one sector in greenhouse, continued to present unacceptable uniformity, but nevertheless it did show a slight increase, from 54.29\% before treatment to $58.38 \%$ after, according to the Bralts \& Kesner (1983) classification. This same problem occurred in a study about dripper clogging due to problems of iron in the irrigation water (Vieira et al., 2004). A product composed of $35 \%$ hydrogen peroxide and $15 \%$ formic acid was used for the cleaning treatment. The irrigation system remained with a water distribution uniformity index within the same range, that is, reasonable, both before and after the chemical treatment. This occurs because, in some cases, there can be a loosening of particles from the inner wall of the pipes which will shift to the inner part of the drippers, increasing the clogging problem (Vieira et al., 2004).

From a practical point of view, the average flow of the drippers in each sector can be considered a good parameter to evaluate the clogging process, and it was used in many pertinent studies (Gilbert \& Ford, 1986; Ravina el al., 1992). Great efficiency was ascertained by this treatment, because the dripper had a $1 \mathrm{~mm}$ orifice diameter for water flow (Cararo, 2004). This was the predominant characteristic in clogging susceptibility, as established by Pizarro (1996) and in a study by Boman (1995), with drippers of different orifice sizes. Therefore, observation of the data on the increase in average flow from the drippers in relation to the diameter of the orifice for water passage proves the efficiency of the treatment since the same also caused an increase in average pressures at the end of the lines and in all evaluated sectors. Emitter clogging resulted in flow uniformity and better hydraulics at the lateral line (Bralts et al., 1982).

The average pressure at the end of the lateral line, before the cleaning treatment, was low due to the increased head loss of the lateral lines caused by the accumulation of impurities, throughout the line, independently of the clogging of the dripper. This consequently causes the decrease of head loss throughout the lateral line. After treatment for unclogging, the drippers at the lateral line caused a decrease head loss throughout the lateral line and an increase of pressure at the end of lines, for every estimated sector (Table 2). The analysis of the effects of irrigation water quality and water distribution uniformity in localized irrigation systems, recommends the use of global uniformity indexes, such as Us (statistical uniformity index) and $\mathrm{Eu}$ (coefficient of emission uniformity). However, they do not permit identifying the causes of clogging. Pressure measurements on lateral lines are the least necessary information to verify hydraulic dimensioning problems (Capra \& Scicolone, 1998).

The statistical coefficient of variation (CV) represents a measurement of the relative dispersion of the data. Given the small magnitude of factors (load loss, slope etc.), and once the CV was determined before the cleaning treatment, the differences found after treatment are related to the unclogging process of the drippers. This statement is confirmed when observing in Figure 3 that the CV was less in all greenhouse spaces after the chemical cleaning process. The difference of the chemical treatment effect estimated by the $\mathrm{CV}$ for the different sectors is due to the variations in the degree of clogging in each sector.

Besides the determination of the coefficient of variation for the flows of the various greenhouse sectors as a measure of the lack of uniformity caused by dripper clogging, the water distribution uniformity index was also determined using the method proposed 
Table 2 - Results and comparison of the chemical treatment evaluation for cleaning the 12 sectors of the irrigation system.

\begin{tabular}{|c|c|c|c|c|c|c|c|c|}
\hline \multirow[b]{2}{*}{ Location } & \multicolumn{2}{|c|}{$\begin{array}{c}\text { Water distribution } \\
\text { uniformity index }\end{array}$} & \multicolumn{2}{|c|}{ Classification } & \multicolumn{2}{|c|}{ Average Flow } & \multicolumn{2}{|c|}{ Average Pressure } \\
\hline & Before $^{(1)}$ & After ${ }^{(2)}$ & Before $^{(1)}$ & After ${ }^{(2)}$ & Before $^{(1)}$ & After ${ }^{(2)}$ & Before $^{(1)}$ & After ${ }^{(2)}$ \\
\hline & \multicolumn{4}{|c|}{-- } & \multicolumn{2}{|c|}{$-\ldots$} & \multicolumn{2}{|c|}{$-\ldots$} \\
\hline $\begin{array}{l}\text { Greenhouse } 1- \\
\text { Space } 1 \text { to } 10\end{array}$ & 66.37 & 83.65 & $\mathrm{Bad}$ & Very Good & 0.75 & 1.47 & 47.26 & 90.21 \\
\hline $\begin{array}{l}\text { Greenhouse } 1- \\
\text { Space } 11 \text { to } 20\end{array}$ & 54.93 & 84.26 & Unacceptable & Very Good & 0.79 & 1.28 & 47.26 & 92.17 \\
\hline $\begin{array}{l}\text { Greenhouse } 2 \text { - } \\
\text { Space } 1 \text { to } 10\end{array}$ & 76.22 & 89.39 & Fair & Very Good & 0.98 & 1.44 & 38.24 & 84.33 \\
\hline $\begin{array}{l}\text { Greenhouse } 2- \\
\text { Space } 11 \text { to } 20\end{array}$ & 73.14 & 93.67 & Fair & Excellent & 0.98 & 1.55 & 41.18 & 100.02 \\
\hline $\begin{array}{l}\text { Greenhouse } 4 \text { - } \\
\text { Space } 1 \text { to } 13\end{array}$ & 77.90 & 83.70 & Fair & Very Good & 0.90 & 1.47 & 9.80 & 88.25 \\
\hline $\begin{array}{l}\text { Greenhouse } 5 \text { - } \\
\text { Space } 1 \text { to } 10\end{array}$ & 75.89 & 89.53 & Fair & Very Good & 1.06 & 1.55 & 19.61 & 103.94 \\
\hline $\begin{array}{l}\text { Greenhouse } 5- \\
\text { Space } 11 \text { to } 20\end{array}$ & 77.31 & 87.60 & Fair & Very Good & 1.02 & 1.51 & 19.61 & 103.94 \\
\hline $\begin{array}{l}\text { Greenhouse } 6- \\
\text { Space } 1 \text { to } 10\end{array}$ & 53.83 & 81.64 & Unacceptable & Very Good & 1.09 & 1.40 & 50.09 & 107.86 \\
\hline $\begin{array}{l}\text { Greenhouse } 6- \\
\text { Space } 11 \text { to } 20\end{array}$ & 73.39 & 93.53 & Fair & Excellent & 1.09 & 1.25 & 53.93 & 74.52 \\
\hline $\begin{array}{l}\text { Greenhouse } 8- \\
\text { Space } 11 \text { to } 20\end{array}$ & 89.98 & 91.30 & Very Good & Excellent & 1.17 & 1.20 & 21.57 & 117.67 \\
\hline $\begin{array}{l}\text { Greenhouse } 9 \text { - } \\
\text { Space } 1 \text { to } 10\end{array}$ & 51.10 & 81.64 & Unacceptable & Very Good & 0.90 & 1.10 & 37.26 & 72.56 \\
\hline $\begin{array}{l}\text { Greenhouse } 9- \\
\text { Space } 11 \text { to } 20\end{array}$ & 54.29 & 58.38 & Unacceptable & Unacceptable & 0.64 & 1.17 & 64.72 & 82.37 \\
\hline
\end{tabular}

${ }^{(1)}$ Values before chemical cleaning treatment. ${ }^{(2)}$ Values after chemical cleaning treatment.

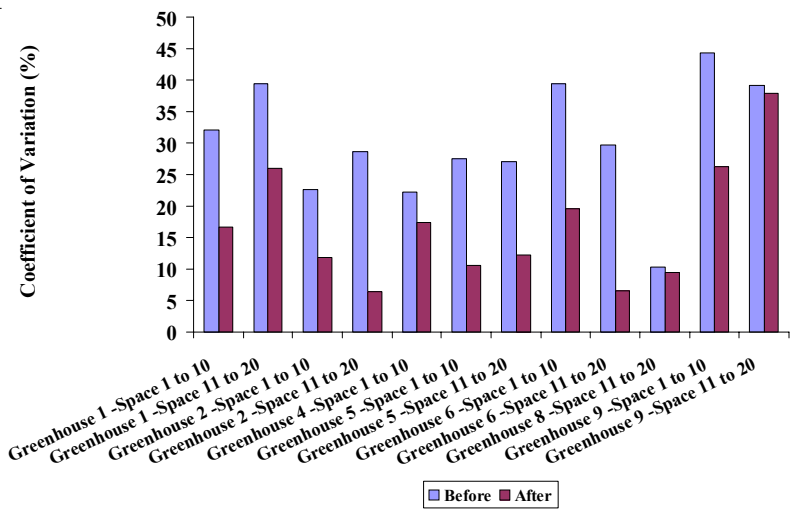

Figure 3 - Coefficient of Variation (CV) before and after cleaning treatment.

by Bralts \& Kesner (1983). This methodology reveals a good correlation with the CV values (Figure 4). This observation is justified by the elevated correlation between the coefficients of variation and the water distribution uniformity that presented a regression equation with a high coefficient of determination $\left(\mathrm{r}^{2}\right)$, at $5 \%$ of probability by the $\mathrm{F}$ test.

Figure 5 shows the classification of the water distribution uniformity index for all sectors before and after the cleaning treatment. The treatment was very efficient because there was a general improvement in

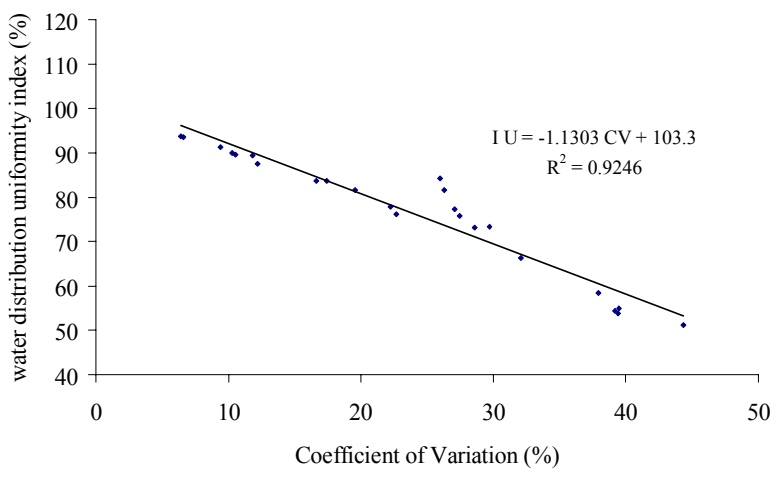

Figure 4 - Correlation between water distribution uniformity index (IU) and the coefficient of variation (CV).

all sectors. Before treatment no sector had an excellent index and practically half were classified as regular. After treatment, three sectors had excellent and eight had very good indexes according to the classification proposed by Bralts \& Kesner (1983), but the largest were for greenhouse one sectors 11 to 20 and greenhouse six and nine sectors 1 to 10 (Table 2), for which the indexes changed from unacceptable to very good, thus demonstrating the efficiency in the chemical treatment of the irrigation water to unclogg drippers. 


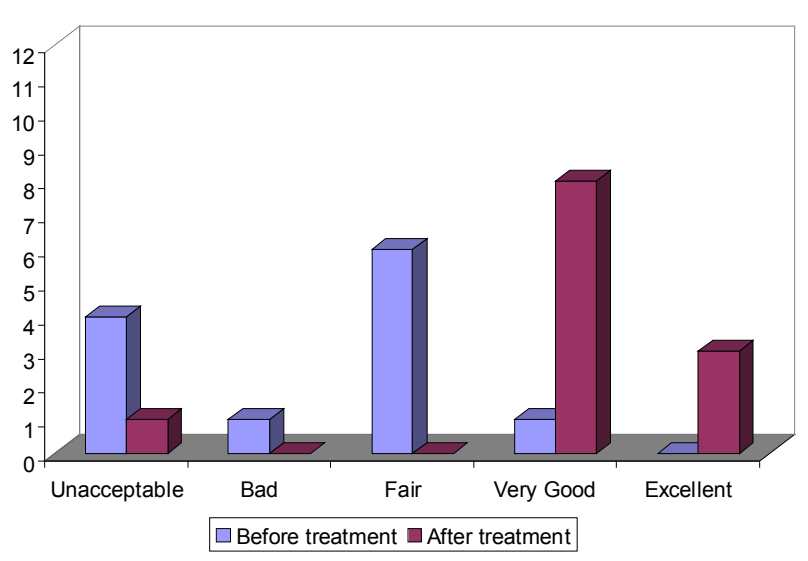

Figure 5 - General situation of the classification of the water distribution uniformity indexes for the 12 sectors before an after cleaning treatment.

\section{CONCLUSIONS}

The analyses of the quality of irrigation water used in the greenhouses indicated that the $\mathrm{pH}$ and iron presented moderate risk for clogging. Phosphorus concentration was considered high because at the prevailing values there was a great proliferation of algae due to the water eutrophization process. It would be of great use to carry out studies to relate the phosphorus problem to the proliferation of algae in the water and quantify these chemical and biological parameters to establish the quality requirements and standards according to foreseen uses, that is, criteria for clogging risk for localized irrigation systems. In the evaluation of 12 sectors of a greenhouse before the chemical treatment for the cleaning, only one sector presented very a good water distribution uniformity index, the remaining were considered fair or unacceptable for the trickle irrigation systems. The treatment with nitric acid $(65 \%)$ at $\mathrm{pH} 5.0$ and sodium hypochlorite $(12 \%)$ was efficient based on water distribution uniformity indexes, evaluated for all sectors of the irrigation system before and after treatment, showing improvement in all of them. This improvement caused a reduction in the coefficient of variation for dripper flow in all sectors. There was a good correlation between water distribution uniformity indexes and the coefficient of variation $(\mathrm{CV})$.

\section{REFERENCES}

AIROLDI, R.P.S. Análise do desempenho de gotejadores e da prevenção do entupimento em irrigação com água residuária. Piracicaba: USP/ESALQ, 2007. 139p. Tese (Doutorado).

AYERS, R.S.; WESTCOT, D.W. Water quality for agriculture. Rome: FAO, 1985. 218p.

BOMAN, B.J. Effects of orifice size on microsprinkler clogging rates. Transactions of the American Society of Agricultural Engineers, v.11, p.839-843, 1995.
BRALTS, F.V.; KESNER, D.C. Drip irrigation field uniformity estimation. Transactions of the American Society of Agricultural Engineers, v.26, p.1369-1374, 1983.

BRALTS, V.F.; WU, I-PAI; GITLIN, H.M. Emitter plugging and drip irrigation lateral line hydraulics. Transactions of the American Society of Agricultural Engineers, v.25, p.12741281,1982

BRANCO, S.M. Hidrobiologia aplicada à engenharia sanitária. 3 ed. São Paulo: CETESB, 1986. 640p.

CARARO, D.C. Manejo de irrigação por gotejamento para aplicação de água residuária visando a minimização do entupimento de emissores. Piracicaba: USP/ESALQ, 2004. 148p.

CAPRA, A.; SCICOLONE, B. Water quality and distribution uniformity in drip/trickle irrigation systems. Journal of Agricultural Engineering Research, v.70, p.355-365, 1998.

CONAMA. Resolução CONAMA 357/2005. Brasília, 2005. Available at www.mma.gov.br. Accessed 21 Jun. 2007.

ENGLISH, S.D. Filtration and water treatment for micro-irrigation. In: INTERNACIONAL DRIP/TRICKLE IRRIGATION CONGRESS, 3., Fresno, 1985. Proceedings. St. Joseph: ASAE, 1985. p.50-57.

FORD, H.A.; TUCKER, D.P.H. Clogging of drip systems from metabolic products of iron and sulfur bacteria. In: INTERNACIONAL DRIP IRRIGATION CONGRESS, 2., San Diego, 1986. Proceedings. San Diego, 1986. p.212-214.

GILBERT, R.G.; FORD, H.W. Operational principles/ emiter clogging. In: NAKAYAMA, F.S.; BUCKS, D.A. Trickle irrigation for crop production: design, operation and management. Amsterdam: Elsevier, 1986. cap.3, p.142163.

KELLER, J.; BLIESNER, R.D. Sprinkle and trickle irrigation. New York: Van Nostrand Reinhold, 1990. 652p.

HILLS, D.J.; BRENES, M.S. Microirrigation of wastewater effluent using drip tape. Transactions of the American Society of Agricultural Engineers, v.17, p.303-308, 2001.

LÉON, S.G.; CAVALLINI, J.M. Tratamento e uso de águas residuárias. Campina Grande: UFPB, 1999. 110p.

MOTA, S. Introdução à engenharia ambiental. Rio de Janeiro: ABES, 1997. 292p.

NAKAYAMA, F.S.; BUCKS, D.A. Water quality in drip/trickle irrigation: a review. Irrigation Science, v.12, p.187-192, 1991.

PESCOD, M.D. Wastewater treatment and use in agriculture. Rome: FAO, 1992. 125p. (FAO Irrigation and Drainage Paper, 47).

PITTS, D.J.; HAMAN, D.Z.; SMAJSTLA, A.G. Causes and prevention of emitter plugging in microirrigation systems. Gainesville: University of Florida, Florida Cooperative Extension Service, 2003. (Bulletin, 258).

PIZARRO, F. Riegos localizados de alta frequencia. 3 ed. Madrid: Mundi Prensa, 1996. 513p.

RAVINA, I.; PAZ, E.; SOFER, Z.; MARCU, A.; SHISHA, A.; SAGI, G. Control of emitter clogging in drip irrigation with reclaimed wastewater. Irrigation Science, v.13, p.129-139, 1992.

RESENDE, R.S. Suscetibilidade de gotejadores ao entupimento de causa biológica e avaliação do desentupimento via cloração da água de irrigação. Piracicaba: USP/ESALQ, 1999. 77p. Dissertação (Mestrado).

RESENDE, R.S.; CASARINI, E.; FOLEGATTI, M. V.; COELHO, R. D. Ocorrência de entupimento de origem biológica em sistema de irrigação por gotejamento. Revista Brasileira de Engenharia Agrícola e Ambiental, v.5, p.156-160, 2001.

RIBEIRO, T.A.P.; PATERNIANI, J.E.S.; AIROLDI, R.P.S.; SILVA, M.J.M. O efeito da qualidade da água no entupimento de emissores e no desempenho de filtros utilizados na irrigação por gotejamento. Irriga, v.9, p.136-149, 2004.

RODRIGO LOPEZ, J.; HERNÁNDEZ ABREU, J.M..; PÉREZ REGALADO, A.; GONZÁLEZ HERNÁNDEZ, J.F. Riego localizado. 2 ed. Madrid: Mundi-Prensa, 1997. 405p. 
SPERLING, M. von. Introdução à qualidade de águas e ao tratamento de esgotos. 2 ed. Belo Horizonte: Segrac, 1996. $243 p$.

TAJRISHY, M.A.; HILLS, D.J.; TCHOBANOGLOUS, G. Pretreatment of secondary effluent for drip irrigation. Journal of Irrigation and Drainage Engineering, v.120, p.716-731, 1994.

VIEIRA, G.H.S.; MANTOVANI, E.C.; SILVA, J.G.F.; RAMOS, M.M.; SILVA, C.M. Recuperação de gotejadores obstruídos devido à utilização de águas ferruginosas. Revista Brasileira de Engenharia Agrícola e Ambiental, v.8, p.1-6, 2004.
ZAZUETA, F.S.; SMAJSTRLA, A.G. Field evaluation of trickle irrigation systems: uniformity of water application. Gainesville: University of Florida, IFAS, 2002. (Bulletin, 265).

Received October 31, 2006

Accepted September 26, 2007 